\title{
Food Safety and Halal Food in the Supply Chain: Review and Bibliometric Analysis
}

\author{
Hana Wahyuni iD, Iwan Vanany iD, Udisubakti Ciptomulyono iD \\ Institut Teknologi Sepulub Nopember (Indonesia) \\ banacatur@umsida.ac.id,vanany@ie.its.ac.id,Udisubak.ti@ie.its.ac.id
}

Received: December 2018

Accepted: June 2019

\begin{abstract}
:
Purpose: Researchers have been actively investigating various issues concerning food safety and halal food in the supply chain. The ultimate goal is to provide guarantees for quality and conformance regarding food standards and demanding expectation from the consumers. We review a set of two-decade food safety and halal food in supply chain (SC) literature from 1990 to 2018 (month of February) in order to pinpoint the problems, models, solution approaches and more importantly, the future directions of this field.
\end{abstract}

Design/methodology/approach: Our method employs the 120 published articles on food safety and halal food in SC research. Various techniques from statistics, bibliometrics, and analytics are systematically deployed to gain insights on how the literature address these two topics.

Findings: The predominant contributing articles, authors, affiliations, and keywords have been reviewed, clustered, and thoroughly analyzed. Through systematic graphical and clustering analyses, four major clusters regarding food safety and two clusters in halal food in SC research have been identified as the most promising and potential future for research opportunities.

Research limitations/implications: This study focuses on articles that discuss food safety and halal.

Practical implications: Our findings provide valuable insights to understand the major clusters of the research endeavour along with the plausible pathways to where they would likely develop in the future. With these insights, researchers and practitioners shall be able to devise initiatives that are of high relevance and significance in the near future.

Social implications: This research provides an understanding to the reader about the relationship between food safety and halal.

Originality/value: This paper provides the first systematic overview of food safety and halal food for supply chain researchers to see the big picture of the field. Serving as the thread connecting research endeavour in these two research areas, our novel work highlights how the work is connected, which research clusters have been the center-of-attention during the last two decades, and consequently, which areas are still lacking an investigation. We believe that people in both academia and industry who are keen to develop a rigorous solution to ensuring food safety and food halal-ness to satisfy global market requirement will be benefitting the most from our analysis.

Keywords: food safety, halal food, supply chain, bibliometric analysis, network analysis, literature review 


\section{To cite this article:}

Wahyuni, H., Vanany, I., \& Ciptomulyono, U. (2019). Food safety and halal food in the supply chain: Review and bibliometric analysis. Journal of Industrial Engineering and Management, 12(2), 373-391. https://doi.org/10.3926/jiem.2803

\section{Introduction}

In recent years, food safety and halal food have been part of the actively researched issues in the food quality literature. As related to the quality, the notion of food "halal"-ness is closely associated with the availability of safe and healthy products. In a similar sense, food safety is arguably emphasizing similar goal, especially from the health aspect (Sani \& Dahlan, 2015). Furthermore, the issues concerning food safety are one of the most important themes to investigate thoroughly, because the lack of food safety has led to various adversarial incidents. In fact, the demand for ensuring food safety is sharply exponentiating in recent years, because the occurrence of unsafe food consumption linked to deaths have been reported globally. In addition to that, news regarding the food contamination with harmful bacteria, viruses, parasites and chemical substances, responsible for more than 200 diseases, ranging from diarrhoea to cancer, have tremendously affected how consumers globally raise their safety standards towards the food products (WHO, 2016). Facing almost the same pattern of increased demand, halal food market has grown significantly over the last five years, because this type of food has now been consumed by both the Muslim and non-Muslim customers. (Rezai, Mohamed \& Nasir-Shamsudin, 2012; Vanany, Maarif \& Soon, 2019). Subsequently, halal, as a necessary-and-sufficient condition for food for Muslim consumers, is currently a highly active theme of study for researchers in various part of the world. Reuters and Standards (2016) reported that the halal food sector would grow approximately $18.3 \%$ of the global food expenditure to US $\$ 1,914$ billion by 2021.

The previous researchers have studied and reported the recent developments regarding food safety and halal food in the supply chain (SC). Among the topics studied, under food safety literature in SC, are food safety management system for fresh products in the SC (Kirezieva, Luning, Jacxsens, Allende, Johannessen, Tondo, et al., 2015), traceability in the food SC (Aung \& Chang, 2014) and multi-player interactions in food safety in an integrated SC (Vitalis, Khaizura \& Son, 2016). Meanwhile, under halal SC literature, topics such as halal SC for manufacturing industries (Ngah, Zainuddin \& Thurasamy, 2014), analysis of halal logistics (Ab Talib, Abdul Hamid \& Zulkafar, 2013), and halal principles in the SC (Tieman, van der Vorst \& Ghazali, 2012) have recently been published in various journals. It is disconcerting that these valuable research endeavour, to some extent, are scattered and there has been no effort to provide a systematic review to make them useful for researchers and practitioners in the field.

In this study, we deploy the bibliometric and network analyses to fulfil the needs of such a systematic review. It is widely known that bibliometric and network analyses are among the powerful techniques to identify and cluster the area of research, which can lead to insightful follow-up analysis. Hence, the objective of this paper is to review food safety and halal food discussion in the SC context using these powerful techniques.

The bibliometric analysis is a systematic analytical technique to identify the most influential authors, their affiliations, the keywords they use and more importantly how these attributes link one work to the other. The network analysis, on the other hand, is a rigorous method to determine the cluster of the research areas, thus revealing the directions and gaps in the future research. The systematic guidelines for the bibliometric analysis by Fahimnia, Sarkis and Davarzani (2015) and network analysis using VOSviewer by Cancino, Merigo, Coronado, Dessouky and Dessouky (2017) were adopted in this research. We applied these to the pre-processed 120 published articles on food safety in SC and 33 published articles on halal food in SC from 1990 to 2018. Our goal is that this systematic review will be helpful for researchers, who want to understand the most recent findings and be able to position their line of work. We also believe that this work will be benefitting the practitioners, who need a concise and insightful summary of the literature to understand the state of the research in food safety and halal food in SC systems. 
This paper is structured as follows: Section 2 introduces the structured research method, including selection of a bibliometric database, including-and-excluding articles and analysing the articles' attributes. Section 3 reports the statistics of the data and the derived classification analysis. The results and detailed bibliometric and network analyses will be presented in section 4 and section 5 , respectively. Finally, section 6 summarizes the discussion and provides conclusions for the opportunity of future research.

\section{Research Methods}

Our review approach embarks with a preliminary goal of exploring the body of literature, following the related articles and tracing the attributes to attain the big picture of research endeavour in food safety and halal food in context of SC. The procedures are comprehensively performed using iterative cycles of defining relevant and informative keywords, querying the literature database, and performing rigorous analytics (Saunders, Lewis \& Thornhill, 2009). We adopted a review of research methods from Fahimnia et al. (2015) and Wamba and Mishra (2017), in which a five-stage research method to achieve similar study objectives are proposed. These five stages are as follows: (1) defining search terms, (2) including-and-excluding articles, (3) selecting the process of articles, (4) performing preliminary data analysis and (5) conducting bibliometric and network analysis. In what follows, we elaborate each of these stages to assure the validity of our findings and to enable the readers to implement this method for systematically performing an analysis-based literature review in their study.

\subsection{Selection of Bibliometric Database and Defining Serach Terms}

We chose the Scopus database, which is one of the largest bibliometric databases of peer-reviewed articles. It is worth mentioning that this database has been providing an access to high-quality refereed articles, published since 1966 (Burnham, 2006) and has about +22,800 series titles from +5,000 publishers, covering 195 million of reference records (Elsevier, 2017). It is noteworthy that most of the journals in Scopus and Web of Science (WoS) are dual-indexed in both databases, alleviating the need of digging from both sources (Gavel \& Iselid, 2008).

We define the search terms or the keywords used for data collection on the food safety in SC research as "Food", "Safety", "Supply Chain", and "Food Safety" or their meaningful combinations; for instance, "Food Safety" AND "Supply Chain" and "Food" AND "Safety" AND "Supply Chain". In context of halal food in SC research, the keywords used are "Halal", "Food", and "Supply Chain". The combinations considered include "Halal Food" AND "Supply Chain" and "Halal" AND "Food" AND "Supply Chain". Using these search terms, we query the database and perform our next stage.

\subsection{Including and Excluding Articles}

The goal of this including-and-excluding stage is to collect and store the most relevant articles that were extracted from query results of the initial search terms. We considered journal articles excluding several source types (such as conference proceedings and book series) and searching the terms within the "title, abstract, and keywords" fields in Scopus database. Our further exclusion criteria encompass the types of the document. We only considered journal articles written in English and published between 1990 and 2018. We also eliminated conferences paper, editorial, erratum/collection, letter, note, review and short survey to ensure that our analysis will be based only on those peer-reviewed, final version, and widely disseminated work. Our query returned 1,694 articles for food and 53 articles for halal food, all in SC research context. The search results including essential attributes of the articles, such as the name of the author(s), title, year, citation count, affiliations, keywords and references were stored in RIS and CSV format for analytical purposes.

\subsection{Selection Process of Articles}

By further processing the query results, we removed article duplication using Endnote software. This selection process is conducted so that we only regard published articles restricted in the related subject area (e.g., business, management and accounting, agricultural and biological sciences, computer science, engineering and decision science). For assuring high relevance, we carefully read the abstract of the candidate articles. As a result, we reduced the article numbers from 1,694 to 120 on food safety and from 53 to 33 on halal food in SC. 


\subsection{Performing Preliminary Data Analyses}

At this stage, we obtained some statistics from the data including (1) the annual distribution of the published articles and (2) the article distribution by years and journals. The annual distribution of published articles is used to understand the trend of related articles, while the article distribution data by years and journals are both used to further analyse and determine which journals are publishing the most articles on food safety and halal food issues in SC context. Further, we classified the articles based on two dimensions: (1) the types of food products being addressed and (2) the types of research methods being utilized. We studied the abstract and the related subsections of these papers carefully to identify these dimensions whenever possible. The statistics and output of the classification analysis are presented in section 3.1 and section 3.2 respectively.

\subsection{Conducting Bibliometric and Network Analysis}

Finally, we conducted the bibliometric analysis using BibExcel and network analysis using VOSviewer. Bibliometric analysis helps us to map the contributing author, affiliation and keywords. In this regard, BibExcel is the preferred tool to utilize because of its high degree of flexibility to deal with large datasets and its compatibility to various network analysis applications, such as Gephi, Pajek and VOSviewer (Persson, Danell \& Schneider, 2009). Following that, the network analysis employing VOSviewer is conducted. It is obvious that our choice of BibExcel provides advantages to integrate these two analyses and avoids the errors related to the misinterpretation and disintegrated metrics. It also noteworthy that this tool has the ability to adjust and, in some sense, 'normalize' the input data obtained from the multi-source databases, including Scopus and Web of Science (Persson et al., 2009). The results of our bibliometric analysis and network analysis are presented in sections 3.3 and 3.4, respectively.

\section{Results of Statistical and Classification Analyses}

In this section, we will discuss our results from the analytical tools and highlight some interesting insights regarding the nature of the published work in the field of food safety and halal food in SC context.

\subsection{Initial Statistical Analysis}

The initial statistical analysis is used to describe the annual distribution of the published articles to understand the trend of the quantity over time. The article distribution by years and journals are used to identify the most publishing journals along with the number of articles published each year.

\subsubsection{The Annual Distribution of the Published Articles}

The annual distribution of the published articles on food safety and halal food in SC context are shown in Figure 1 (a. food safety in SC and b. halal food in SC). The first article addressing the food safety issues was published in 1990, while the first one addressing food safety in SC context was published a decade later, in 2000. Figure 1a shows that there is a significant increase in food safety concerns in SC context, as shown by the trend of publications within the 17-year period. Meanwhile, the first article of halal food research was published in 2008. Two years later, an arguably short period of time, an article discussing halal food issue in SC context was published in 2010.

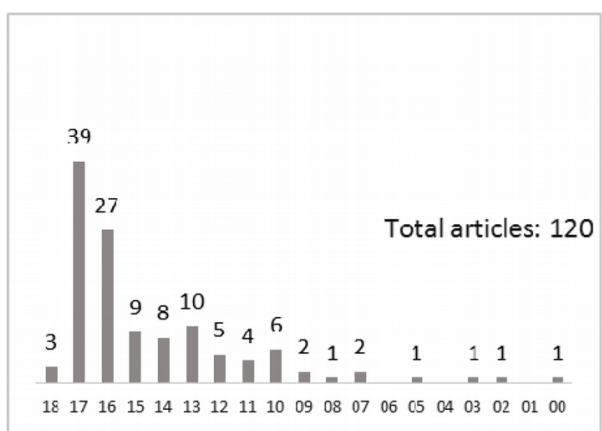

(a)

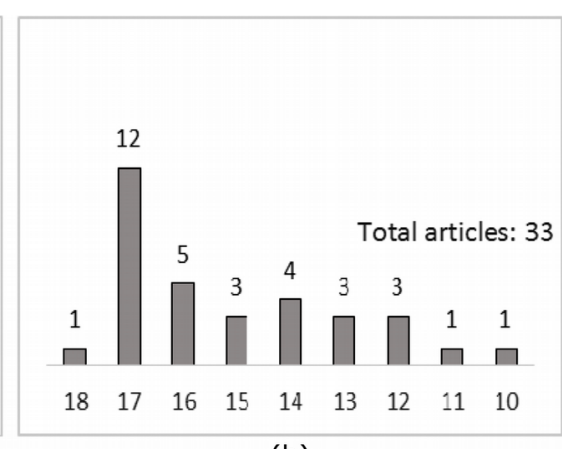

(b)

Note: $\mathrm{x}$-axis $=$ amount of articles and $\mathrm{y}$-axis $=$ year

Figure 1. Annual distribution of articles on (a) food safety in SC (b) halal food in SC 
Figure 1a shows the number of published articles on food safety in SC by years. In this figure, it is obvious that the number of published articles increased during the period of 2000-2017. It can be observed that the last two years, $2016(27$ articles $(22.50 \%))$ and 2017 (39 articles (32.50\%)), are both representing big jumps in terms of number of published articles, indicating that the food safety in SC research has recently attracted significant attention from many researchers and would very likely continue to do so, if not amplify, in the near future. In Figure 1b, the number of articles on halal food in SC also increased from 2011 to 2017, with the most publication in 2017 (12 articles (36.36\%)). These findings align with Reuters and Standards (2016) prediction that the demand concerning food safety and halal food, especially that applied in the whole chain, will continue to exponentiate in the foreseeable future.

\subsubsection{Article Distribution by Journals and Years}

Our review of 120 articles on food safety in SC from 84 journals and 33 articles on halal food in SC topic from 24 journals, reveals that over thirty-three percent of the articles in food safety in SC have been published in ten flagship journals (see Table 1). It is interesting to note that the issues of food safety in SC are highlighted, addressed and published in journals from various fields, such as agricultural and biological sciences, business, management, accounting, decision science and computer science, indicating the multi-disciplinary nature of the problems. It can be noted that The Food Control (17 articles (14.17\%)) and British Food Journal (5 articles (4.17\%)) both published more articles in this regard than other journals in consideration. The annual distribution of the published articles on food safety in SC by various journals is shown in detail in Table 1.

\begin{tabular}{|c|c|c|c|c|c|c|c|c|c|c|c|c|c|c|c|c|c|c|c|c|c|}
\hline No & Name of Journal & 0 & 1 & 2 & 3 & 4 & 5 & 6 & 7 & 8 & 9 & 10 & 11 & 12 & 13 & 14 & 15 & 16 & $\mid 17$ & 18 & Total \\
\hline 1 & Food Control & & & & & & & & 1 & & & & & 1 & 1 & 1 & 2 & 5 & 6 & & 17 \\
\hline 2 & British Food Journal* & & & & 1 & & & & & & & & & & 1 & & 1 & 1 & 1 & & 5 \\
\hline 3 & $\begin{array}{l}\text { Food Research } \\
\text { International }\end{array}$ & & & & & & & & & & & 1 & & 1 & & & & & & 1 & 3 \\
\hline 4 & $\begin{array}{l}\text { Trends in Food Science } \\
\text { and Technology * }\end{array}$ & & & & & & & & & & & & & & & & & 1 & 1 & 1 & 3 \\
\hline 5 & $\begin{array}{l}\text { Journal of Marketing } \\
\text { Channels }\end{array}$ & & & & & & & & & & & & & & & & & & 2 & & 2 \\
\hline 6 & Meat Science* & & & & & & & & 1 & & & & & & & & & & 1 & & 2 \\
\hline 7 & $\begin{array}{l}\text { Sustainability } \\
\text { (Switzerland) }\end{array}$ & & & & & & & & & & & & & & & & & 1 & 1 & & 2 \\
\hline 8 & $\begin{array}{l}\text { Critical Reviews in Food } \\
\text { Science and Nutrition }\end{array}$ & & & & & & & & & & & & & & & & & 1 & 1 & & 2 \\
\hline- & - & - & - & - & - & - & - & - & - & - & - & - & - & - & - & - & - & - & - & - & - \\
\hline- & - & - & - & - & - & - & - & - & - & - & - & - & - & - & - & - & - & - & - & - & - \\
\hline 81 & $\begin{array}{l}\text { China Economic } \\
\text { Review }\end{array}$ & & 1 & & & & & & & & & & & & & & & & & & 1 \\
\hline 82 & $\begin{array}{l}\text { Journal of Agricultural } \\
\text { Economics }\end{array}$ & & & & & & & & & & 1 & & & & & & & & & & 1 \\
\hline 83 & $\begin{array}{l}\text { Asian- Australasian } \\
\text { Journal of Animal } \\
\text { Science }\end{array}$ & & & & & & & & & & & & & & & & & & 1 & & 1 \\
\hline 84 & $\begin{array}{l}\text { Journal of Industrial } \\
\text { Engineering and } \\
\text { Management }\end{array}$ & & & & & & & & & & & & & & & & & & 1 & & 1 \\
\hline & Total & 1 & 0 & 1 & 1 & 0 & 1 & 0 & 2 & 1 & 3 & 5 & 4 & 5 & 9 & 8 & 9 & 27 & 39 & 3 & 120 \\
\hline
\end{tabular}

Table 1. Distribution of food safety in supply chain articles by years and journals 
Table 2 shows the distribution of articles on halal food in SC by different years and journals from a total of 24 journals. The five most publishing journal is the Journal of Islamic Marketing (6 articles (18.18\%)), British Food Journal (6.06\%), Industrial Management and Data System (6.06.1\%), International Business Management (2 articles $(6.06 \%))$ and International Journal of Supply Chain Management $(6.06 \%)$. This indicates that research related to halal food in SC is also an active and multi-disciplinary area spanning from business, management, and accounting, agricultural and biological sciences, computer science, to decision sciences.

\begin{tabular}{|c|c|c|c|c|c|c|c|c|c|c|c|}
\hline \multirow[b]{2}{*}{ No } & \multirow[b]{2}{*}{ Name of Journal } & \multicolumn{9}{|c|}{ Publication Year } & \multirow[b]{2}{*}{ Amount } \\
\hline & & 10 & $' 11$ & 12 & ${ }^{\prime} 13$ & ${ }^{\prime} 14$ & ${ }^{\prime} 15$ & ${ }^{9} 16$ & 17 & 918 & \\
\hline 1 & Journal of Islamic Marketing & & 1 & 1 & & & 1 & & 2 & 1 & 6 \\
\hline 2 & International Journal of Food Properties & & & & & & & & 1 & & 1 \\
\hline 3 & Food Policy & & & & & & & & 1 & & 1 \\
\hline 4 & $\begin{array}{l}\text { International Journal of Supply Chain } \\
\text { Management }\end{array}$ & & & & & & & & 2 & & 2 \\
\hline 5 & British Food Journal & & & & & & & & 2 & & 2 \\
\hline 6 & Industrial Management and Data Systems & & & & & & & & 2 & & 2 \\
\hline 7 & Social Science Pakistan & & & & & & & 1 & & & 1 \\
\hline 8 & Supply Chain Management & & & & & & & & 1 & & 1 \\
\hline 9 & Journal of Macro-Marketing & & & & & & & 1 & & & 1 \\
\hline 10 & Meat Science & & & & & & & 1 & & & 1 \\
\hline 11 & Jurnal Pengurusan & & & & & & & 1 & & & 1 \\
\hline 12 & International Business Management & & & 1 & & & & 1 & & & 2 \\
\hline 13 & $\begin{array}{l}\text { Asian Pasific Journal of Marketing and } \\
\text { Logistic }\end{array}$ & & & & & & 1 & & & & 1 \\
\hline 14 & Journal fo Food Product Marketing & & & & & 1 & & & & & 1 \\
\hline 15 & $\begin{array}{l}\text { Journal of Internastional Food and } \\
\text { Agribusiness Marketing }\end{array}$ & & & & & 1 & & & & & 1 \\
\hline 16 & $\begin{array}{l}\text { Industrial Engineerin and Management } \\
\text { System }\end{array}$ & & & & & 1 & & & & & 1 \\
\hline 17 & Sustainabilty (Switzerland) & & & & & 1 & & & & & 1 \\
\hline 18 & American Journal of Enviromental Science & & & & 1 & & & & & & 1 \\
\hline 19 & International Journal of Lean Six SIgma & & & & 1 & & & & & & 1 \\
\hline 20 & Advance in Natural and Applied Science & & & 1 & & & & & & & 1 \\
\hline 21 & Advance Science Letters & & & & & & & & 1 & & 1 \\
\hline 22 & Enviromental Law and Management & 1 & & & & & & & & & 1 \\
\hline 23 & $\begin{array}{l}\text { Food Additive and Contaminants Part A } \\
\text { Chemistry, Analysis Control, Exposure and } \\
\text { Risk Management }\end{array}$ & & & & & & 1 & & & & 1 \\
\hline 24 & $\begin{array}{l}\text { Recents Patents on Food Nutrition and } \\
\text { Agriculture }\end{array}$ & & & & 1 & & & & & & 1 \\
\hline & Total & 1 & 1 & 3 & 2 & 5 & 3 & 5 & 12 & 1 & 33 \\
\hline
\end{tabular}

Table 2. Distribution articles of halal food in supply chain by journals and years 
There are 7 journals that published articles about the food safety and halal food in SC, namely: (1) Journal of Islamic Marketing, (2) British Food Journal, (3) Industrial Management and Data Systems, (4) Food Additives and Contaminants Part A Chemistry Analysis Control Exposure And Risk Assessment, (5) Food Policy, (6) Meat Science and (7) Sustainability Switzerland. These results align with the commonly acknowledged idea that there is indeed a close relationship between food safety and halal food issues in SC and integratedly addressing both issues simultaneously would lead to highly effective and robust SC strategy.

\subsection{Classification Analysis}

\subsubsection{Types of Research Methods}

According to Chen, Zhao, Tang, Price, Zhang and Zhu (2017), the various research methods used by the researchers on food safety and halal food in SC context can generally be divided into four classes: survey, case study, concept development and modelling. In this context, a survey is a research method that is useful to investigate characteristics of the population under study. A case study is highly effective to understand various real-life phenomena. The concept development describes the methodological approach developed to further advance science and human understanding. Finally, the modelling is an approach that simplifies a problem in the form of mathematical models that are tractable to solve in a closed-form or, at the very least, yield to a numerically attainable solution. Overall, the distribution of the methods used is shown in Figure 2. As shown, nearly 40 percent (47 articles $(39 \%)$ ), i.e. almost half of the food safety in SC articles, were using the survey method, which is well aligned with our findings in the case of halal food in SC with 14 articles (46\%).

Investigating the practice of the utilized methods deeper, we found that the surveys were mostly conducted through questionnaires or interviews using the structured questions. In food safety SC research, such as the study by Cavaliere, Aiello, Perri, Amico, Martial, Thibaut et al. (2016), researchers analysed the characteristics of organic supply chain relationships focusing on processing and retail sectors. In halal SC research, Ali, Kader, Yunus, Mohezar \& Nazri (2017b) used a cross-sectional approach in their survey. Meanwhile, the concept development in food safety SC and halal SC leads to the integration with other variables, such as quality (Zhang, Fu, Wang, Tang, Zhao \& Zhang, 2017), global trends and developments (King, Cole, Farber, Eisenbrand, Zabaras, Fox et al., 2017), and certification (Ab Talib, 2017; White \& Samuel, 2016). Case studies are used to investigate the growth of various types of bacteria, that degrade the quality of food products in manufacturing or distribution systems (Pang, 2017; Ssemanda, Reij, Bagabe, Muvunyi, Joosten \& Zwietering, 2017) concerning the food safety issues. On halal SC, case studies are found closely related to risk management (Ali, Tan, Pawar \& Makhbul, 2014) because of the various processes involved in SC and the implementation of halal behaviour in certain regions or countries (Heiman, Gordon, \& Zilberman, 2017). Finally, in terms of modelling method, mathematical equations are used to describe the behaviour of the bacterial growth or some measure of risks to be mitigated (Mohammed, Wang \& Li, 2017; Nascimento, Carminati, Silva, Silva, Bernardi \& Copetti, 2018).

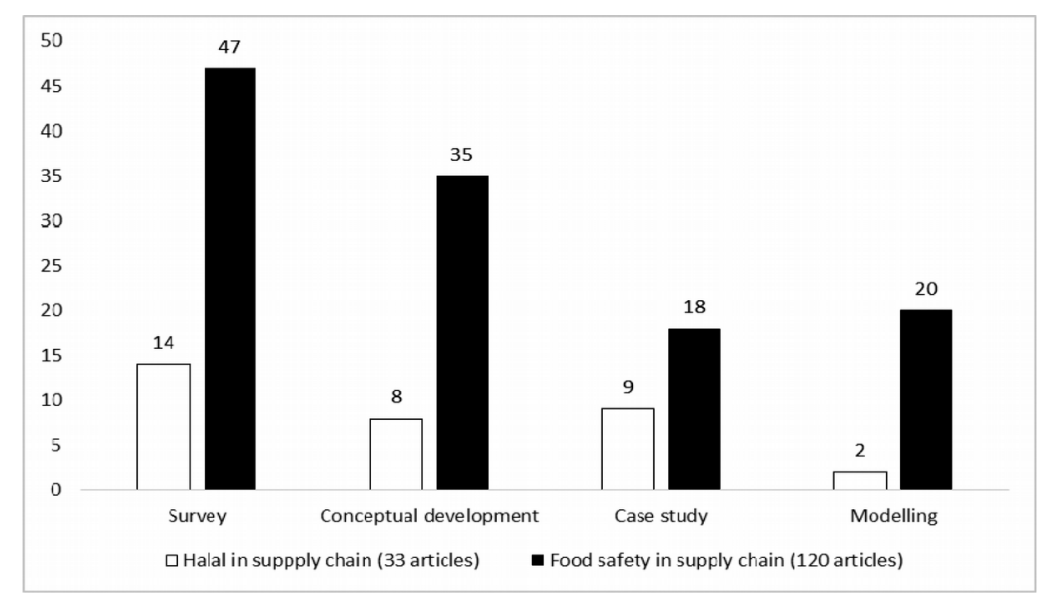

Figure 2. Types of research methods 


\subsubsection{Type of Food Products}

The articles on food safety and halal food in SC appear to extend to several product types. The types of food product shown in Figure 3 are general terms, and therefore not included in the analysis. The most common application has been for meat products (10 articles), which are inherently and widely understood, where issues concerning food safety and halal food in SC have frequently been raised. In the articles related to food safety in SC, Telligman, Worosz and Bratcher (2017) conducted research to explore the consumers' top-of-mind food safety belief about the local beef, using the survey method. They found that the consumers tend to be more confident on the local beef or those sourced from close proximity, which, in turn, leads to the higher food safety confidence compared to those sourced from unknown places.

In the articles about halal food in SC, most of the applications have also been around meat products. Mohammed et al. (2017) developed a framework using RFID-enabled monitoring system and applied it in context of halal meat products. In their subsequent research, they investigated the economic feasibility of a three-echelon halal meat product in SC (Mohammed et al., 2017). Farouk, Pufpaff and Amir (2016) discussed why poor practices and animal welfare abuse are still occurring during the halal meat production and how to reduce such undesired practices through some initiatives, including staff training and CCTV installation, among many others.

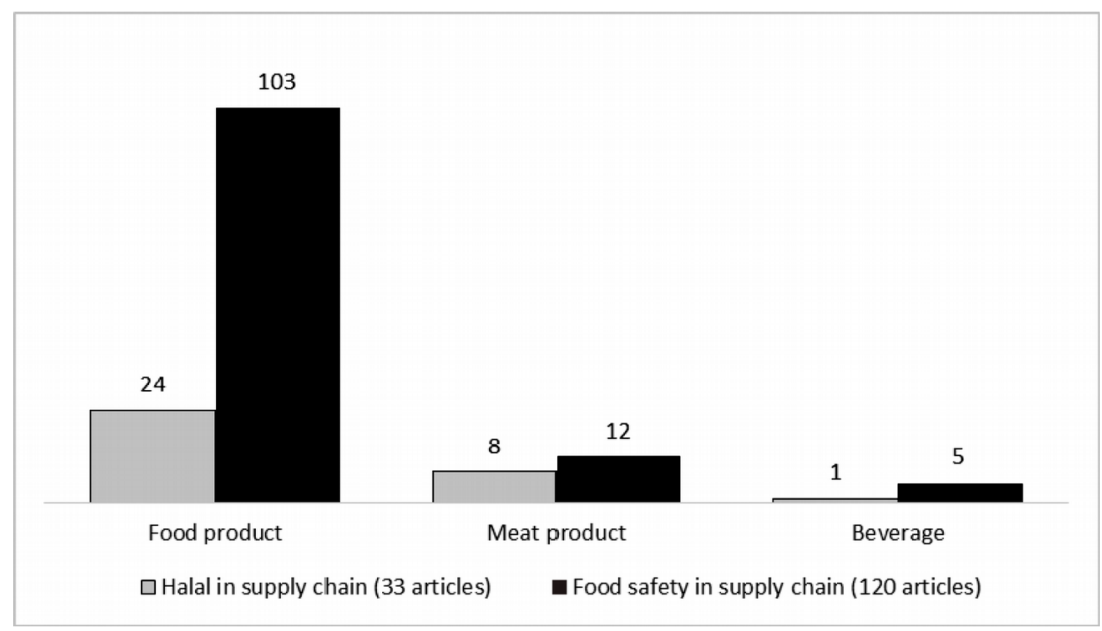

Figure 3. Type of food product

\section{Bibliometric Analysis}

In this section, we conducted the bibliometric analysis using BibExcel. Leveraging on the ability to provide comprehensive network analysis tools, such as Gephi, Pajek and VOSviewer, our analysis is cognizantly adopted and comprehensively performed using various inbuilt features of BibExcel. We refer readers to the study of Persson et al (2009) for more details. The pre-processed input data, containing various attributes of the articles from the previous stages, are in the form of RIS format from Scopus, which are compatible to be fetched directly into BibExcel. We focused on analysing a set of information, such as author(s), year, document title, journal, affiliation, keywords, citation count and references. In what follows, we discuss our findings regarding the influence of the authors, the citation of the articles and the statistics of the keyword based on BibExcel and Excel analytics.

\subsection{Influence of Authors}

We analysed the influence of authors by extracting the field "author" from the data file and recorded the number of publications from each author. Table 3 shows the list of top ten contributing authors and the number of publications they have authored or co-authored. In research related to the food safety in SC, Jacxsens, L. is the highest contributing authors with 8 publications, followed by Uyttendaele M. with 7 publications. In Halal food in SC, Ali and Tan are at the top with 5 publications each, followed by Manzouri and Tieman with 4 publications each. Please see Table 3 for more details. 


\begin{tabular}{|l|c|l|c|}
\hline \multicolumn{1}{|c|}{ Author } & \multicolumn{1}{c|}{$\begin{array}{c}\text { Number of } \\
\text { publications }\end{array}$} & \multicolumn{1}{c|}{ Author } & Number of publications \\
\hline 1. Jacxsens, L. & 8 & 1. Ali, M.H. & 5 \\
\hline 2. Uyttendaele, M. & 7 & 2. Tan, K.H. & 5 \\
\hline 3. Luning, P.A. & 4 & 3. Manzouri, M. & 4 \\
\hline 4. Raspor, P. & 2 & 4. Tieman, M. & 3 \\
\hline 5. Manning, L. & 2 & 5. Ab-Rahman, M.N. & 2 \\
\hline 6. Kirezieva, K. & 2 & 6. Li, X. & 2 \\
\hline 7. Hammoudi, A. & 1 & 7. Makhbul, Z.M. & 2 \\
\hline 8. Zheng, L. & 1 & 8. Mohammed, A. & 2 \\
\hline 9. Desmarchelier, P. & 1 & 9. Othman, S.N. & 2 \\
\hline 10. Monaghan & 1 & 10. Wang, Q. & 3 \\
\hline
\end{tabular}

Table 3. Top 10 contributing authors by number of publications related to food safety and halal food in the SC

\subsection{Affiliation of the Authors}

The affiliation of the authors is analysed by extracting the field "author's affiliation" from the data file and the number of articles is recorded. For each affiliation, the country where the organization is located was identified. Table 4 shows the list of the top ten affiliations based on the number of paper published by the affiliating authors. In research related to food safety in SC, the three top contributing organizations are from the United States. This may be because the researchers in several US universities tend to be more aware towards the societies' demand for food safety, and thus have spent more effort in investigating this issues using SC perspectives. In case of halal food in SC, the top ten organizations are from Malaysia, such as Universiti Kebangsaan Malaysia and from the United Kingdom, such as the University of Nottingham. These institutions are frequently represented by more prolific authors, including Ali, Mohd Helmi, and Tan, Kimhua.

\begin{tabular}{|c|c|c|c|}
\hline \multicolumn{2}{|l|}{ Food Safety in Supply Chain } & \multicolumn{2}{|l|}{ Halal Food in Supply Chain } \\
\hline The affiliation of author - Country & Frequency & The affiliation of author- Country & Frequency \\
\hline $\begin{array}{l}\text { 1. Food and Drug Administration - United } \\
\text { States }\end{array}$ & 7 & 1. Universiti Kebangsaan Malaysia - Malaysia & 9 \\
\hline 2. Michigan State University - United States & 5 & 2. University of Nottingham - United Kingdom & 5 \\
\hline 3. University of California - United States & 4 & 3. Universiti Putra Malaysia - Malaysia & 4 \\
\hline 4. University of Tasmania - Australia & 2 & 4. University of Malaya - Malaysia & 4 \\
\hline 5. Institute of Food Technologists -Canada & 2 & 5. Universiti Teknologi MARA - Malaysia & 3 \\
\hline 6. Cranfield University - United Kingdom & 1 & 6. University Utara Malaysia - Malaysia & 2 \\
\hline 7. China Agricultural University - China & 1 & 7. University of Portsmouth - United Kingdom & 2 \\
\hline $\begin{array}{l}\text { 8. Chinese Academy of Agricultural Sciences - } \\
\text { China }\end{array}$ & 1 & 8. Universiti Tun Abdul Razak - Malaysia & 1 \\
\hline 9. University of Queensland - United Kingdom & 1 & 9. Politeknik Sultan Haji Ahmad Shah - Malaysia & 1 \\
\hline 10. University of Saskatchewan - Canada & 1 & 10. National Coordinator Malaysia - Malaysia & 1 \\
\hline$\cdots$ & $\cdots$ & $\cdots$ & $\cdots$ \\
\hline 80. University of Ljubljana - Slovenia & 1 & 29. Universitas Islam Indonesia - Indonesia & 1 \\
\hline Total & 94 & Total & 51 \\
\hline
\end{tabular}

Table 4. The 10 most frequent affiliations of the authors (by country) 


\subsection{Keyword Used by the Authors}

The keyword is an important information provided by the authors to help readers to find the relevant papers. The authors' keywords were extracted from Scopus data file using BibExcel and were summarised using Excel spreadsheet. The 20 most frequent keywords are presented in Table 5. This list is derived from a collection of 561 keywords from 120 papers related to the food safety in SC research and 160 keywords from 33 papers about the halal food in SC research. In food safety, it is not surprising that "food safety" and "supply chain" are among the most popular keywords. This demonstrates that the most popular keywords are actually the initial search terms of this study. In halal food, the four most popular keywords were also identified.

\begin{tabular}{|c|c|c|c|}
\hline \multicolumn{2}{|c|}{ Food Safety in Supply Chain } & \multicolumn{2}{|c|}{ Halal Food in Supply Chain } \\
\hline Keyword & Frequency & Keyword & Frequency \\
\hline 1. Food safety & 75 & 1. Halal & 15 \\
\hline 2. Supply chain & 24 & 2. supply chains & 8 \\
\hline 3. Microorganism & 22 & 3. Halal supply chain management & 5 \\
\hline 4. Risk & 21 & 4. Supply chain management & 4 \\
\hline 5. Food supply chain & 19 & 5. Malaysia & 4 \\
\hline 6. Hazard & 16 & 6. halal logistics & 4 \\
\hline 7. Vegetables & 12 & 7. RFID & 3 \\
\hline 8. Country & 11 & 8. Food integrity & 3 \\
\hline 9. Agricultural & 6 & 9. Halal food & 3 \\
\hline 10. Meat & 5 & 10. Halal supply chain & 3 \\
\hline 11. Foodborne disease & 5 & 11. Islam & 3 \\
\hline 12. Food industry & 4 & 12. Supply chain integration & 3 \\
\hline 13. Halal & 3 & 13. Barriers & 2 \\
\hline 14. Contamination & 3 & 14. Challenges & 2 \\
\hline 15. Certification & 2 & 15. Food industry & 2 \\
\hline 16. Economic impact & 2 & 16. Food supply chain integrity & 2 \\
\hline 17. Aflatoxins & 2 & 17. Halal food supply chain & 2 \\
\hline 18. Food defence & 2 & 18. Halal Malaysia & 2 \\
\hline 19. Food chain & 2 & 19. Illegal food supply & 2 \\
\hline 20. Traceability & 2 & 20. Lean practices & 2 \\
\hline$\cdots$ & $\cdots$ & $\cdots$ & $\cdots$ \\
\hline Total & 561 & Total & 159 \\
\hline
\end{tabular}

Table 5. The 20 most frequent keywords by the authors

\section{Network Analysis}

The tools or software needed to conduct the network analysis include those that provide graphical and clustering ability, such as HistCite Graph Maker, Pajek, VOSviewer and Gephi. VOSViewer is used in this paper to analyse the citation of articles based on global citation and total link strength. Besides, it also provides both graphical and clustering analyses. As such, we utilize VOSviewer to provide general graphs in terms of bibliographical coupling, co-citation, co-authorship, citation and co-occurrence of keywords (Eck \& Waltman, 2010). 


\subsection{Citation of Articles}

The number of citations reflects the importance of particular articles in that area of research (Garfield, 1972). The importance of an article can be measured by the number of citations it receives. It should be noticed that such citation analysis has been criticized. However, for practical reasons, MacRoberts and MacRoberts (2010) believe that citation analysis is still one of the most commonly used techniques to analyse the importance of an article in the literature. To analyse the contribution of papers that are accepted by other authors, we used the VOSviewer to determine the most cited articles. The total link strength (TLS) was also recorded to indicate the connections with other articles.

\begin{tabular}{|c|c|c|c|c|c|}
\hline \multicolumn{3}{|c|}{ Food Safety in Supply Chain } & \multicolumn{3}{|c|}{ Halal Food in Supply Chain } \\
\hline Author(s) - Year & $\begin{array}{l}\text { Global } \\
\text { citation }\end{array}$ & $\begin{array}{c}\text { Total Link } \\
\text { Strength (TLS) }\end{array}$ & Author(s) - Year & $\begin{array}{l}\text { Global } \\
\text { citation }\end{array}$ & $\begin{array}{l}\text { Total Link } \\
\text { Strength (TLS) }\end{array}$ \\
\hline $\begin{array}{l}\text { 1. Marucheck, Greis, Mena } \\
\text { and Cai (2011) }\end{array}$ & 118 & 218 & 1. Tieman (2011) & 62 & 52 \\
\hline $\begin{array}{l}\text { 2. Van Boxstael, Habib, } \\
\text { Jacxsens, De Vocht, Baert, } \\
\text { Van De Perre et al. (2013) }\end{array}$ & 75 & 110 & 2. Tieman et al. (2012) & 44 & 105 \\
\hline $\begin{array}{l}\text { 3. Borchers, Teuber, Keen \& } \\
\text { Gershwin (2010) }\end{array}$ & 59 & 18 & 3. Tieman (2015) & 15 & 62 \\
\hline 4. Jacxsens et al. (2010) & 56 & 97 & $\begin{array}{l}\text { 4. Manzouri, Ab-Rahman, } \\
\text { Saibani and Mohd-Zain } \\
\text { (2013) }\end{array}$ & 12 & 30 \\
\hline 5. Kleter and Marvin (2009) & 45 & 18 & 5. Ali et al. (2014) & 10 & 90 \\
\hline $\begin{array}{l}\text { 6. Amaya-González, Santos- } \\
\text { Álvarez, Miranda-Ordieres } \\
\text { and Lobo-Castañón (2013) }\end{array}$ & 42 & 18 & $\begin{array}{l}\text { 6. Tieman and Van } \\
\text { Nistelrooy (2014) }\end{array}$ & 10 & 112 \\
\hline $\begin{array}{l}\text { 7. Stringer, Sang and } \\
\text { Croppenstedt (2009) }\end{array}$ & 22 & 54 & 7. Ali, Tan \& Ismail (2017a) & 7 & 8 \\
\hline $\begin{array}{l}\text { 8. Tonsor, Schroeder and } \\
\text { Pennings (2009) }\end{array}$ & 22 & 38 & 8. Razzak et al. (2015) & 7 & 17 \\
\hline 9. Wang et al. (2012) & 20 & 48 & 9. Farouk et al. (2016) & 5 & 4 \\
\hline $\begin{array}{l}\text { 10. Mahian and Arianfar } \\
\text { (2016) }\end{array}$ & 0 & 51 & $\begin{array}{l}\text { 10. Soon, Chandia and } \\
\text { Regenstein (2017) }\end{array}$ & 4 & 46 \\
\hline$\cdots$ & $\cdots$ & $\cdots$ & $\cdots$ & $\cdots$ & $\ldots$ \\
\hline $\begin{array}{l}\text { 120. Raspor and Jevšnik } \\
\text { (2016) }\end{array}$ & 0 & 0 & 33. Pocklington (2010) & 0 & 0 \\
\hline Total & 847 & 5144 & Total & 205 & 1666 \\
\hline
\end{tabular}

Table 6. The 10 most cited articles

Table 6 presents a list of the top ten most frequently cited paper. It is noteworthy that the most cited paper is by Marucheck et al. (2011) with 118 citations, followed by the paper by Van Boxtael et al. (2013) with 75 citations, in research about food safety in SC. Marucheck et al. (2011) investigated how the field of operation management can provide a new perspective on the challenges regarding product safety and security, throughout the whole supply chain. Another important work was made by Van Boxtael et al. (2013), which represented food safety issues in fresh product from the perspectives of food safety experts.

In the research related to halal food in SC a paper by Tieman (2011) is the most frequently cited article with 62 citations, followed by a paper by Tieman et al. (2012) with 44 citations. Tieman (2011) investigated the basic requirements for halal supply chains to ensure the integrity of halal food. Tieman with Van der Vorst and Ghazali, 
in 2012, also introduced a new framework (halal supply chain model) to optimize the design of halal food supply chains, providing more prescriptive analysis to the problems.

\subsection{Graphical and Clustering Analysis}

We used VOSviewer software to provide the graphical analysis for the research related to food safety and halal food in SC based on the bibliometric data, with which we visualized the co-citation of journals and co-occurrence of keywords. The graph of journal co-citation is used to visualize the most cited journals and the network links to indicate those journals that are highly co-cited. Figure 4 presents the results of journal co-citation visual for the research about food safety and halal food in SC.

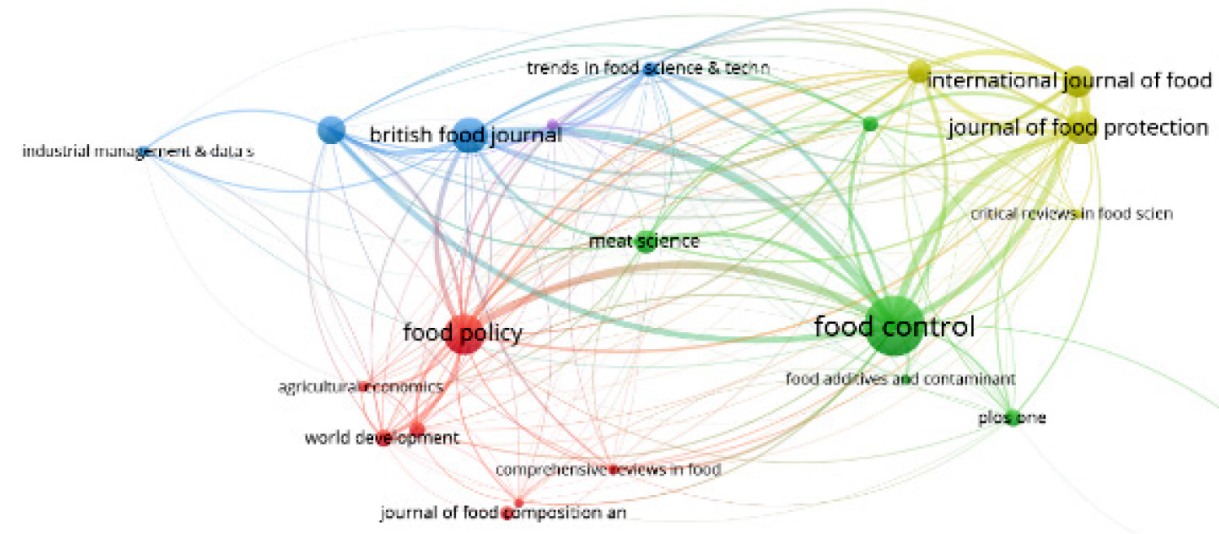

food addis contarn

\section{As vosviewer}

(a)

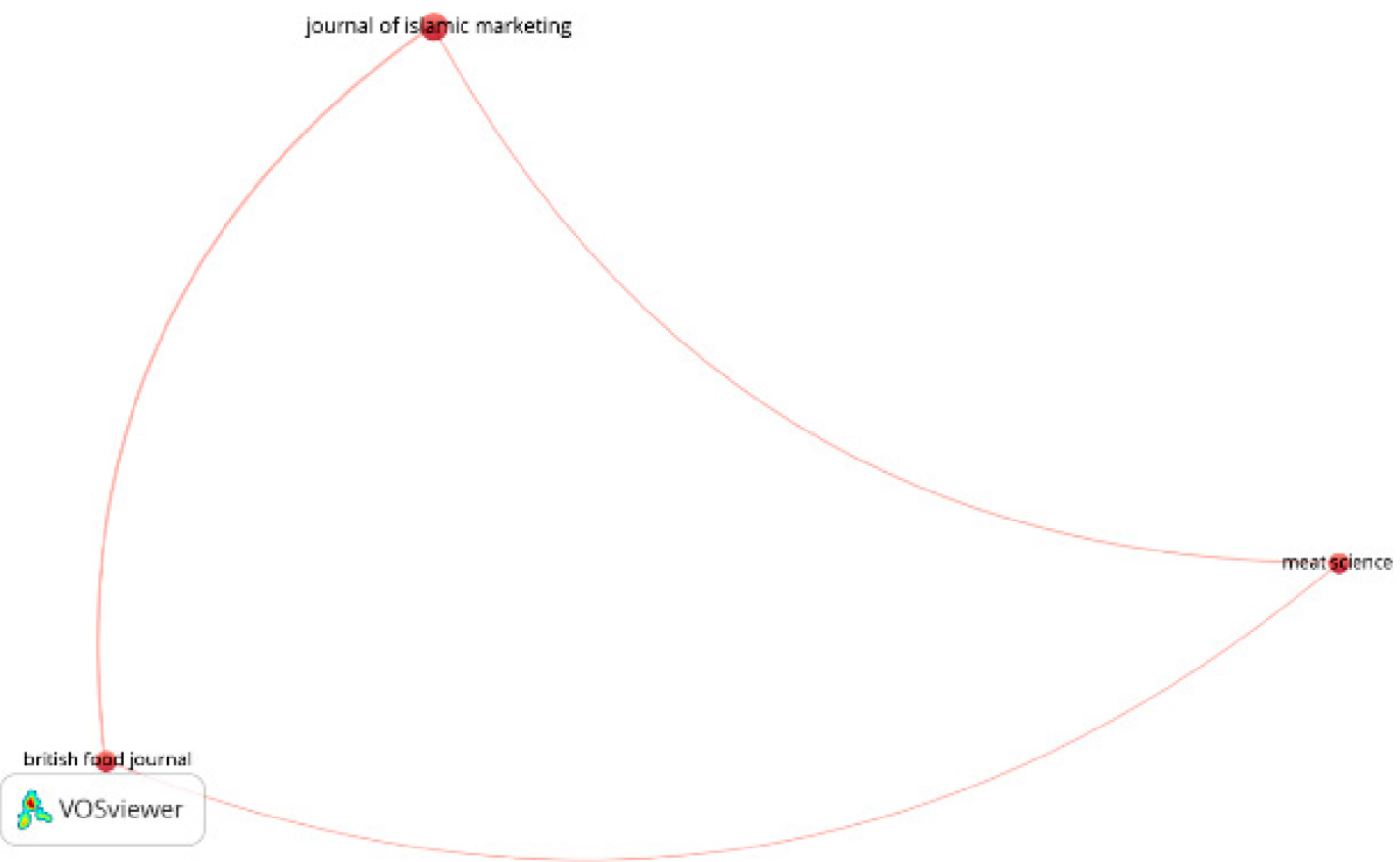

(b)

Figure 4. Co-citation of journals cited in the research about (a) food safety in SC and (b) halal food in SC 
In case of food safety in SC, Food Control is the most cited journal and has the largest network. British Food Journal, Journal of Food Protection, International Journal of Food Microbiology and Food Policy are also highly cited. This is in-line with the number of distribution of articles by journals and years. In halal food in SC, Journal of Islamic Marketing is the most cited journal followed by British Food Journal and Meat Science.

In clustering analysis, a graph of the keyword co-occurrence is used to present the major cluster of research and the network connections based on the abstracts of articles. Using VOSviewer software, we identified five major clusters for research related to food safety in SC and two clusters for halal food in SC (see Figure 5).

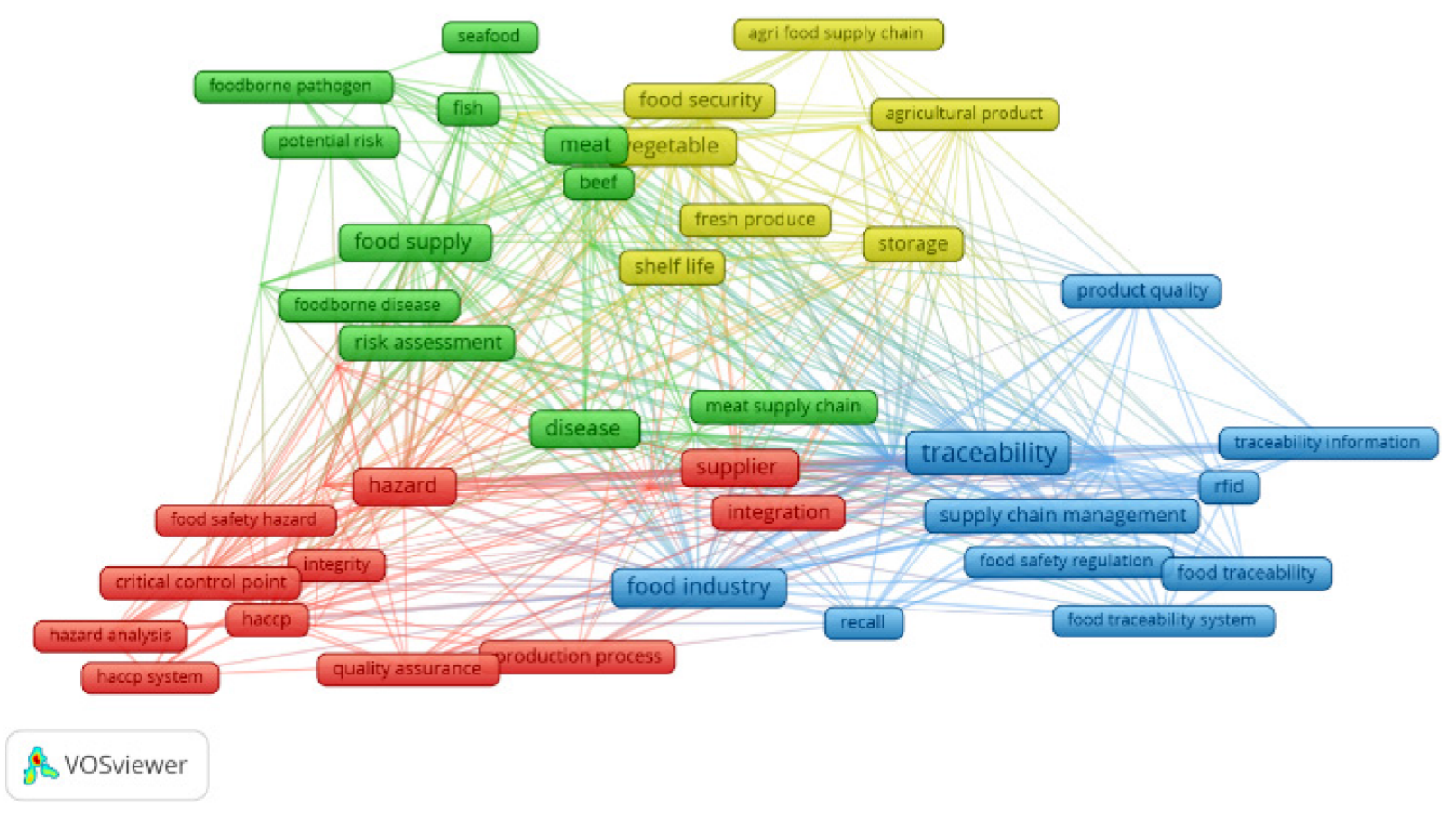

(a)

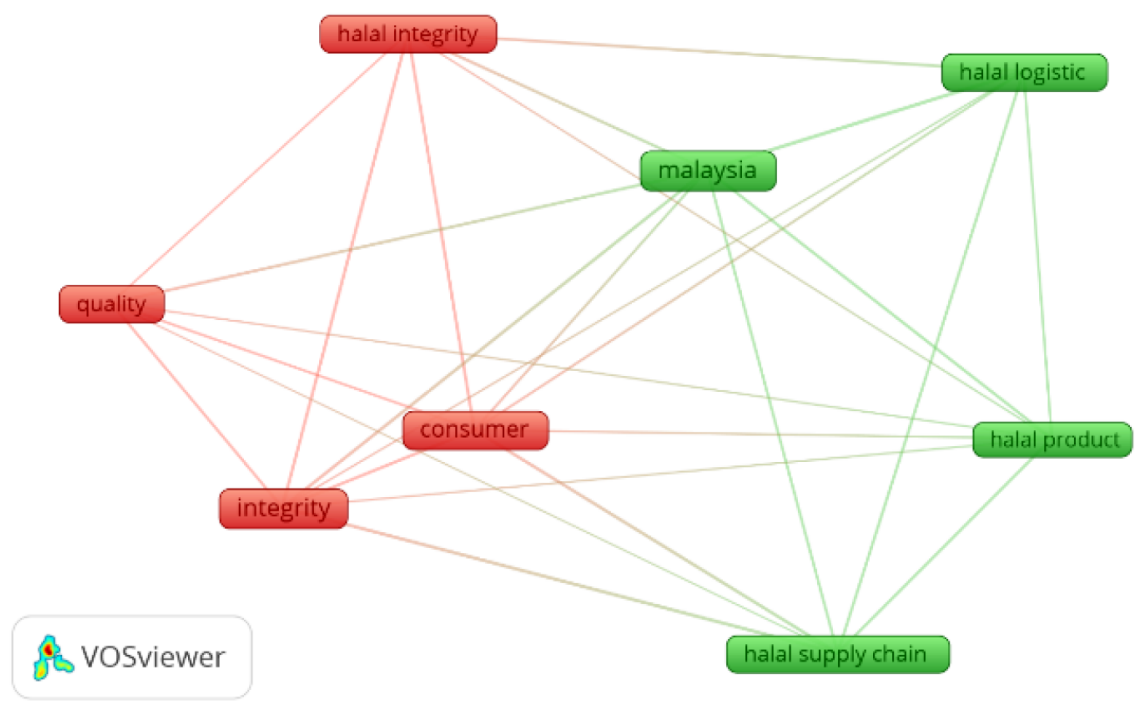

(b)

Figure 5. Co-occurrence of keywords in research related to (a) food safety in SC and (b) halal food in SC 
The links (edges) indicate the number of links between an item (node) with the other items. The TLS indicate the total strength of the link between an item with the other items (Eck \& Waltman, 2010). The TLS values are recorded to highlight the strength of the relationships between keywords (items/nodes) and the links' strength (edges weight) of the keyword. In Table 7, the top 10 keywords from each cluster based on their TLS values were recorded.

We analysed and evaluated the objectives of the papers identified with the same keywords to determine the research focus for each cluster. In the research about food safety in SC, the main research issue in cluster 1 is on managing the hazard as the danger of risks in food (including HACCP (Hazard Analysis and Critical Control Points) because of its popularity) in supply chain context. This approach has been applied to chemical, microbiological, physical hazards (Van Asselt, Van Der Fels-Klerx, Marvin, Van De Veen \& Groot, 2017), and emerging hazards (Kleter \& Marvin, 2009), Manning and Soon (2013) reviewed the methods for assessing food safety risk as a key element for HACCP approach.

\begin{tabular}{|c|c|c|c|}
\hline \multicolumn{4}{|c|}{ Food safety suplly chain cluster } \\
\hline Keyword & TLS & Keyword & TLS \\
\hline \multicolumn{2}{|c|}{ Cluster 1} & \multicolumn{2}{|l|}{ Cluster 2} \\
\hline Hazard & 174 & Traceability & 282 \\
\hline HACCP & 111 & Technology & 280 \\
\hline Supplier & 103 & Food industry & 202 \\
\hline Critical control point & 88 & Traceability system & 196 \\
\hline Hazard analysis & 73 & Supply chain management & 92 \\
\hline Food sector & 71 & Integration & 86 \\
\hline Quality assurance & 58 & RFID & 86 \\
\hline Certification & 58 & Food traceability & 71 \\
\hline Production process & 57 & Recall & 63 \\
\hline Contaminant & 44 & Traceability information & 52 \\
\hline \multicolumn{2}{|c|}{ Cluster 3} & \multicolumn{2}{|l|}{ Cluster 4} \\
\hline Contamination & 194 & Vegetable & 139 \\
\hline Food supply & 136 & Fruit & 110 \\
\hline Disease & 123 & Storage & 102 \\
\hline Risk assessment & 116 & Shelf life & 76 \\
\hline Plant & 83 & Fresh produce & 71 \\
\hline Probability & 57 & Transportation & 61 \\
\hline Meat product & 47 & Food security & 58 \\
\hline Meat supply chain & 45 & Dairy product & 34 \\
\hline Livestock & 43 & Food waste & 33 \\
\hline Foodborne disease & 42 & Agricultural product & 31 \\
\hline Foodborne pathogen & 36 & Food safety standard & 30 \\
\hline Food safety concern & 28 & Microbiological safety & 22 \\
\hline Potential risk & 23 & $\begin{array}{l}\text { Agricultural food supply } \\
\text { chain }\end{array}$ & 16 \\
\hline
\end{tabular}

\begin{tabular}{|c|c|}
\hline \multicolumn{2}{|c|}{ Halal supply chain cluster } \\
\hline Keyword & TLS \\
\hline \multicolumn{2}{|c|}{ Cluster 1} \\
\hline Integrity & 92 \\
\hline Consumer & 78 \\
\hline Halal integrity & 68 \\
\hline Quality & 38 \\
\hline \multicolumn{2}{|c|}{ Cluster 2} \\
\hline Malaysia & 106 \\
\hline Halal supply chain & 77 \\
\hline Halal logistic & 71 \\
\hline Halal product & 42 \\
\hline
\end{tabular}

Table 7. The 10 most used keywords in each cluster (TLS co-occurrence indicator) 
Cluster 2 mainly concentrates on developing traceability system, as technology information tools, for food safety to avoid food contamination incidents in a supply chain. The study by Marucheck et al. (2011) is often cited, because it provides four areas of the operations management, including traceability system as innovative solutions for food product safety. Wang, Yue and Zhou (2017) proposed a better food traceability system to evaluate the food safety in the supply chain and provided this evaluation information to customers.

Cluster 3 mainly focuses on reducing and avoiding contamination and diseases for food safety. For contamination issues, developing and applying Aptamers (Amaya-González et al., 2013), analysing the security of the commodities and imported food supplements (Zach, Doyle, Bier \& Czuprynski, 2012) and various decontamination technologies (Khan, Miskeen, Khalil, Phull, Kim \& Oh, 2016) were conducted. For disease, analysing, practical application of ALOP (Appropriate Level of Protection) and FSO (Food Safety Objective) in case of Salmonella in chicken meat (Gkogka, Reij, Gorris \& Zwietering, 2013) and various microbial pathogens in salads (Mir, Shah, Mir, Dar, Greiner \& Roohinejad, 2018), are the topics actively discussed by the researchers.

Cluster 4 mainly concentrates on managing vegetables and fruit for food safety using technology, such as irradiation (Shahbaz, Akram, Ahn \& Kwon, 2016) and post-harvest technology (Mahajan, Caleb, Gil, Izumi, Colelli, Watkins et al., 2017). The investigation and review of food safety for vegetable and fruits, for problems related to the international food supply chain context (Ait-Hou, Grazia \& Malorgio, 2015), customer behaviours (Cheng, Jiang, Zhang, You, Zhang, Zhou et al., 2016), microbial testing integration (Duvenage \& Korsten, 2017), micro-organisms indication (Ssemanda et al., 2017) were elaborated and discussed.

In research related to halal food in SC, the main research issues in cluster 1 mainly focuses on halal food integrity. The halal food integrity is mainly conducted to maintain good quality to satisfy the customers' expectation. Ali et al. (2017a) developed a framework for achieving and maintaining food supply chain integrity in context of halal food. Ali et al. (2017b) investigated the relationships between supply chain integration and halal food supply chain integrity and the impact of halal food supply integrity on the firm's performance. Tan, Ali, Makhbul and Ismail (2017) studied the impact of external integration on compliance with halal standards, as an example of product integrity, within the food industries. Ali et al. (2017a) and Ali et al. (2017b) highlighted the fully-integrated supply chain investigation in halal food integrity for future research. In cluster 2, Malaysia is a popular research object about halal food in SC to investigate several issues related to the halal supply chain (Tieman, 2011; Tieman et al., 2012), and lean in halal supply chain (Manzouri et al., 2013; Manzouri, Ab-Rahman \& Mohd-Zain, 2014).

\section{Discussion and Conclusions}

This paper presented an overview of the distribution of literature on food safety and halal food in SC by bibliometric and network analyses. A set of 120 papers published on food safety and 33 papers published on halal food in SC research were collected by querying Scopus database using predefined keywords. The pre-processing by analysing the title of the papers and their abstracts, and by removing those that are irrelevant to the topic, is also conducted to ensure the validity of the analysis.

The prevalent contributing authors, affiliation and keywords have been extracted to allow for an analytical approach. With network analyses, major research areas-four on food safety and two on halal food in SC research have been identified. These results yield to some clusters of influential keywords found in the literature, which could be utilized as a guide for young researchers to gain further insights regarding the emerging areas of research in context of food safety and halal food in SC.

\section{Declaration of Conflicting Interests}

The authors declared no potential conflicts of interest with respect to the research, authorship, and/or publication of this article.

\section{Funding}

Our findings may help researchers to understand the current research overview and the status of their work. In addition to that, our findings also can help the practitioners to understand the practical challenges about food safety and halal food that span along the supply chain system. 


\section{References}

Ab Talib, M.S. (2017). Motivations and Benefits of Halal Food Safety Certification. Journal of Islamic Marketing, 8 (4), 605-624. https://doi.org/10.1108/JIMA-08-2015-0063

Ab Talib, M.S., Abdul Hamid, A.B., \& Zulkafar, M.H. (2013). Halal Supply Chain Critical Success Factors: Literature Review. Journal of Islamic Marketing, 6(1), 44-71. https:/ doi.org/10.1108/JIMA-07-2013-0049

Ait-Hou, M., Grazia, C., \& Malorgio, G. (2015). Food safety standards and international supply chain organization: A case study of the Moroccan fruit and vegetable exports. Food Control, 55, 190-199. https://doi.org/10.1016/j.foodcont.2015.02.023

Ali, M.H., Tan, K.H., \& Ismail, M.D. (2017a). A supply chain integrity framework for halal food. British Food Journal, 119(1), 20-38. https://doi.org/10.1108/BFJ-07-2016-0345

Ali, M.H., Tan, K.H., Pawar, K., \& Makhbul, Z.M. (2014). Extenuating food integrity risk through supply chain integration: The case of halal food extenuating food integrity risk through supply chain integration: The case of halal food. Industrial Engineering \& Management Systems, 13(2), 154-162. https://doi.org/10.7232/iems.2014.13.2.154

Ali, R., Kader, M.A.R.A., Yunus, N.K.M.., Mohezar, S., \& Nazri, M. (2017b). Factor influencing supplier selection process among Muslim food operators: A qualitative study. Advanced Science Letters, 23(4), 3057-3060.

https://doi.org/10.1166/asl.2017.7652

Amaya-González, S., Santos-Álvarez, N.D.L., Miranda-Ordieres, A.J.M., \& Lobo-Castañón, M.J. (2013). Aptamerbased analysis: A promising alternative for food safety control. Sensors, 13(12), 16292-16311. https://doi.org/10.3390/s131216292

Aung, M.M., \& Chang, Y.S. (2014). Traceability in food supply chain: Safety and quality perspective. Food Control, 39, 172-184. https://doi.org/10.1016/j.foodcont.2013.11.007

Borchers, A., Teuber, S.S., Keen, C.L., \& Gershwin, M.E. (2010). Food Safety. Clinic RevAllerg Immunol, 39, 94-141. https://doi.org/10.1007/s12016-009-8176-4

Burnham, J.F. (2006). Scopus database: A review. Biomedical digital libraries, 3(1), 1. https://doi.org/10.1186/1742-55813-1

Cavaliere, C., Aiello, M., Perri, C.D., Amico, E., Martial, C., Thibaut, A. et al. (2016). Functional connectivity substrates for tDCS response in minimally conscious state patients. Frontiers in Cellular Neuroscience, 10, 1-7. https://doi.org/10.3389/fncel.2016.00257

Cancino, C., Merigo, J.M., Coronado, F., Dessouky, Y., \& Dessouky, M. (2017). Forty years of computers and industrial engineering: A bibliometric analysis. Computers and Industrial Engineering, 113, 614-629. https://doi.org/10.1016/j.cie.2017.08.033

Chen, L., Zhao, X., Tang, O., Price, L., Zhang, S., \& Zhu, W. (2017). Supply chain collaboration for sustainability: A literature review and future research agenda. International Journal of Production Economics, 194, 73-87. https://doi.org/10.1016/j.ijpe.2017.04.005

Cheng, L., Jiang, S., Zhang, S., You, H., Zhang, J., Zhou, Z. et al. (2016). Consumers' behaviors and concerns on fresh vegetable purchase and safety in Beijing urban areas, China. Food Control, 63, 10-109. https://doi.org/10.1016/j.foodcont.2015.11.024

Duvenage, S., \& Korsten, L. (2017). Assessment of foodborne pathogen presence in the peach supply chain and its potential risk to the end consumer. Food Control, 78, 374-382. https://doi.org/10.1016/j.foodcont.2017.03.003

Eck, N.J., \& Waltman, L. (2010). Software survey: VOSviewer, a computer program for bibliometric mapping. Scientometrics, 84(2), 523-538. https://doi.org/10.1007/s11192-009-0146-3

Elsevier (2017), The bibliographic indexing leader. Available at: https://www.elsevier.com/researchintelligence/campaigns/get-to-know-scopus/the-bibliographic-indexing-leader

Fahimnia, B., Sarkis, J., \& Davarzani, H. (2015). Green supply chain management: A review and bibliometric analysis. International Journal Production Economics, 162, 101-114. https://doi.org/10.1016/j.ijpe.2015.01.003 
Farouk, M.M., Pufpaff, K.M., \& Amir, M. (2016). Industrial halal meat production and animal welfare: A review. Meat Science, 120, 60-70. https://doi.org/10.1016/j.meatsci.2016.04.023

Garfield, E. (1972). Citation analysis as a tool in journal evaluation. Essays of an Information. Scientist, 1, 527-544. https://doi.org/10.1126/science.178.4060.471

Gavel, Y., \& Iselid, L. (2008). Web of Science and Scopus: A journal title overlap study. Online Information Review, 32(1), 8-21. https://doi.org/10.1108/14684520810865958

Gkogka, E., Reij, M.W., Gorris, L.G.M., \& Zwietering, M.H. (2013). Risk assessment strategies as a tool in the application of the Appropriate Level of Protection (ALOP) and Food Safety Objective (FSO) by risk managers. International Journal of Food Microbiology, 167(1), 8-28. https://doi.org/10.1016/j.ijfoodmicro.2013.04.013

Heiman, A., Gordon, B., \& Zilberman, D. (2017). Food beliefs and food supply chains: The impact of religion and religiosity in Israel. Food Policy. Online. https://doi.org/10.1016/j.foodpol.2017.07.007

Jacxsens, L., Luning, P.A., Van Der Vorst, J.G.A.J., Devlieghere, F., Leemans, R., \& Uytteendaele, M. (2010). Simulation modelling and risk assessment as tools to identify the impact of climate change on microbiological food safety - The case study of fresh produce supply chain. Food Research International, 43, 1925-1935. https://doi.org/10.1016/j.foodres.2009.07.009

Khan, I., Miskeen, S., Khalil, A.T., Phull, A.R., Kim, S.J., \& Oh, D.H. (2016). Foodborne pathogens: Staphylococcus aureus and listeria monocytogenes an unsolved problem of the food industry. Pakistan Journal of Nutrition, 15(6), 505-514. https://doi.org/10.3923/pjn.2016.505.514

King, T., Cole, M., Farber, J.M., Eisenbrand, G., Zabaras, D., Fox, E.M. et al. (2017). Food safety for food security: Relationship between global megatrends and developments in food safety. Trends in Food Science and Technology, 68, 160-175. https://doi.org/10.1016/j.tifs.2017.08.014

Kirezieva, K., Luning, P.A., Jacxsens, L., Allende, A., Johannessen, G.S., Tondo, E.C., et al. (2015). Factors affecting the status of food safety management systems in the global fresh produce chain. Food Control, 52, 85-97. https://doi.org/10.1016/j.foodcont.2014.12.030

Kleter, G.A., \& Marvin H.J.P. (2009). Indicators of emerging hazards and risks to food safety. Food and Chemical Toxicology, 47(5). https://doi.org/1022-1039. 10.1016/j.fct.2008.07.028

MacRoberts, M.H., \& MacRoberts, B.R. (2010). Problems of citation analysis: A Study of uncited and seldom-cited influences. Journal of The American Society for Information Science and Technology, 61(1), 1-13.

https://doi.org/10.1002/asi.21228

Mahajan, P.V., Caleb, O.J., Gil, M.I., Izumi, H., Colelli, G., Watkins, C.B. et al. (2017). Quality and safety of fresh horticultural commodities: Recent advances and future perspectives. Food Packaging and Shelf Life, 14, 2-11. https://doi.org/10.1016/j.fps1.2017.08.001

Mahian, R.A., \& Arianfar, A. (2016). Food safety management and regulation: A systemic review. International Journal of PharmTech Research, 9(7), 381-387.

Manning, L., \& Soon, J.M. (2013). Mechanisms for assessing food safety risk. British Food Journal, 115(3), 460-484. https://doi.org/10.1108/00070701311314255

Manzouri, M., Ab-Rahman, M.N., Saibani, N., \& Mohd-Zain, C.R.C. (2013). Lean supply chain practices in the Halal food. International Journal of Lean Six Sigma, 4(4), 389-408. https:/ doi.org/10.1108/IJLSS-10-2012-0011

Manzouri, M., Ab-Rahman, M.N., \& Mohd-Zain, C.R.C. (2014). Increasing production and eliminating waste through lean tools and techniques for Halal food companies. Sustainability (Switzerland), 6(12), 9179-9204. https://doi.org/10.3390/su6.129179

Marucheck, A., Greis, N., Mena, C., \& Cai, L. (2011). Product safety and security in the global supply chain: Issues, challenges and research opportunities. Journal of Operations Management, 29(7-8), 707-720.

https://doi.org/10.1016/j.jom.2011.06.007 
Mir, S.A., Shah, M.A., Mir, M.M., Dar, B.N., Greiner, R., \& Roohinejad, S. (2018). Microbiological contamination of ready-to-eat vegetable salads in developing countries and potential solutions in the supply chain to control microbial pathogens. Food Control, 85, 235-244. https://doi.org/10.1016/j.foodcont.2017.10.006

Mohammed, A., Wang, Q., \& Li, X. (2017). A study in integrity of an RFID-monitoring HMSC. International Journal of Food Properties, 20(5), 1145-1158. https://doi.org/10.1080/10942912.2016.1203933

Nascimento, M.S., Carminati, J.A., Silva, I.C.R.N., Silva, D.L., Bernardi, A.O., \& Copetti ,M.V. (2018). Salmonella, Escherichia coli and Enterobacteriaceae in the peanut supply chain: From farm to table. Food Research International, 105, 930-935. https:/ / doi.org/10.1016/j.foodres.2017.12.021

Ngah, A.H., Zainuddin, Y., \& Thurasamy, R. (2014). Adoption of halal supply chain among Malaysian halal manufacturers: An exploratory study. Social and Bahavior Science, 129, 388-395. https://doi.org/10.1016/j.sbspro.2014.03.692

Pang, A. (2017). Product safety failure and restoring reputation across markets: Fonterra's management of the 2013 bacterial contamination crisis. Journal of Marketing Channels, 24(3-4), 136-152. https://doi.org/10.1080/1046669X.2017.1393231

Persson, O., Danell, R., \& Schneider, J.W. (2009). How to use Bibexcel for various types of bibliometric analysis. Celebrating Scholarly Communication Studies: A Festschrift for Olle Persson at His 60th Birthday, International Society for Scientometrics and Informetrics.

Pocklington, D. (2010). Industry soundings. Environmental Law and Management, 22(6), 328-330.

Raspor P., \& Jevšnik, M. (2016). Food Supply Chains vs. Food Supply Nets. In: Nedović V., Raspor P., Lević J., Tumbas Šaponjac V., Barbosa-Cánovas G. (eds), Emerging and Traditional Technologies for Safe, Healthy and Quality Food. Food Engineering Series (pp. 9-32). Springer. https://doi.org/10.1007/978-3-319-24040-4_2

Razzak, M.A., Hamid, S.B.A., \& Ali, M.E. (2015). A lab-on-a-chip-based multiplex platform to detect potential fraud of introducing pig, dog, cat, rat and monkey meat into the food chain. Food Additives and Contaminants - Part A Chemistry, Analysis, Control, Exposure and Risk Assessment, 32 (11), 1902-1913.

https://doi.org/10.1080/19440049.2015.1087060

Rezai, G., Mohamed, Z., \& Nasir-Shamsudin, M. (2012). Non-Muslim consumers' understanding of Halal principles in Malaysia. Journal of Islamic Marketing, 3(1), 35-46. https:/ / doi.org/10.1108/17590831211206572

Reuters, T., \& Standard, D. (2016). State of the global Islamic economy report 2016/17. Dubai: Thomson Reuters.

Sani, A.N., \& Dahlan, H.A. (2015). Current trend for food safety and Halal measures. ASEAN Community Conference Bangi, Malaysia, 11-12 November.

Saunders, M., Lewis, P., \& Thornhill, A. (2009). Research methods for business students (5th ed.). Harlow: Pearson Education.

Shahbaz, H.M., Akram, K., Ahn, J.-J., \& Kwon, J.-H. (2016). Worldwide Status of Fresh Fruits Irradiation and Concerns about Quality, Safety, and Consumer Acceptance. Critical Reviews in Food Science and Nutrition, 56(11), 1790-1807. https://doi.org/10.1080/10408398.2013.787384

Ssemanda, J.N., Reij, M., Bagabe, M.C., Muvunyi, C.M., Joosten, H., \& Zwietering M.H. (2017). Indicator microorganisms in fresh vegetables from "farm to fork" in Rwanda. Food Control, 75, 126-133. https://doi.org/10.1016/j.foodcont.2016.12.031

Stringer, R., Sang, N., \& Croppenstedt, A. (2009). Producers, Processors, and Procurement Decisions: The Case of Vegetable Supply Chains in China. World Development, 37 (11), 1773-1780.

https://doi.org/10.1016/j.worlddev.2008.08.027

Soon, J.M., Chandia M., \& Regenstein, J.M. (2017). Halal integrity in the food supply chain. British Food Journal, 119(1), 39-51. https://doi.org/10.1108/BFJ-04-2016-0150

Tan, K.H., Ali, M.H., Makhbul, Z.M., \& Ismail, A. (2017). The impact of external integration on halal food integrity. Supply Chain Management, 22(2), 186-199. https://doi.org/10.1108/SCM-05-2016-0171 
Telligman, A.L., Worosz, M.R., \& Bratcher, C.L. (2017). A qualitative study of Southern U.S. consumers' top of the mind beliefs about the safety of local beef. Appetite, 109, 1-10. https://doi.org/10.1016/j.appet.2016.10.031

Tieman, M. (2011). The application of Halal supply chain management: In depth interview. Journal of Islamic Marketing, 2(2), 186-195. https://doi.org/10.1108/17590831111139893

Tieman M. (2015). Halal clusters. Journal of Islamic Marketing, 6 (1), 2-21. https://doi.org/10.1108/JIMA-05-2014-0034

Tieman, M., van der Vorst, J.G.A.J., \& Ghazali, M.C. (2012). Principle in halal supply chain management. Journal of Islamic Marketing, 3(3), 217-243. https://doi.org/10.1108/17590831211259727

Tieman M., \& \& van Nistelrooy M. (2014). Perception of Malaysian Food Manufacturers Toward Halal Logistics. Journal of International Food and Agribusiness Marketing, 26(3), 218-233. https://doi.org/10.1080/08974438.2013.833572

Tonsor, G.T., Schroeder T.C., \& Pennings, J.M.E. (2009). Factors impacting food safety risk perceptions. Journal of Agricultural Economics, 60(3), 625-644. https://doi.org/10.1111/j.1477-9552.2009.00209.x

Van Asselt, E.D., Van Der Fels-Klerx, H.J., Marvin, H.J.P., Van De Veen, H.V.B., \& Groot, M.N. (2017). Overview of food safety hazards in the European dairy supply chain. Comprehensive Reviews in Food Science and Food Safety,16(1), 59-75. https:// doi.org/10.1111/1541-4337.12245

Van Boxtael, S., Habib, I., Jacxsens, L., De Vocht, D., Baert, L., Van De Perre, E. et al. (2013). Food safety issues in fresh produce: Bacterial pathogens, viruses and pesticide residues indicated as major concerns by stakeholders in the fresh produce chain. Food Control, 32, 190-197. https://doi.org/10.1016/j.foodcont.2012.11.038

Vanany, I., Maarif, G.A., \& Soon, J.M.. (2019). Application of multi-based Quality Function Deployment (QFD) model to improve halal meat industry. Journal of Islamic Marketing, 10(1), 97-124. https://doi.org/10.1108/JIMA-102017-0119

Vitalis, R.E, Nor-Khaizura, M.A.R., \& Son, R. (2016). Actor network theory in food safety. International Food Research Journal, 23(6), 2319-2325. http://wwwifri.upm.edu.my/23 (06) 2016/(2).pdf

Wamba, S.F., \& Misra, D. (2017). Big data integration with business processes: A literature review. Business Process Management Journal, 23(3), 477-492. https://doi.org/10.1108/BPMJ-02-2017-0047

Wang, J., Yue, H., \& Zhou, Z. (2017). An improved traceability system for food quality assurance and evaluation based on fuzzy classification and neural network. Food Control, 79, 363-370.

https://doi.org/10.1016/j.foodcont.2017.04.013

Wang, X., Li, D., \& Shi, X. (2012). A fuzzy model for aggregative food safety risk assessment in food supply chains. Production Planning and Control, 23(5), 377-395. https://doi.org/10.1080/09537287.2011.561812

White, G.R.T., \& Samuel, A. (2016). Fairtrade and halal food certification and labeling: Commercial lessons and religious limitations. Journal of Macromarketing, 36(4), 388-399. https://doi.org/10.1177/0276146715620236

WHO, World Health Organization. (2016). https://www.who.int/gho/publications/world health statistics/2016/en/

Zach, L., Doyle, M.E., Bier, V., \& Czuprynski, C. (2012). Systems and governance in food import safety: A U.S. perspective. Food Control, 27(1), 153-162. https://doi.org/10.1016/j.foodcont.2012.03.013

Zhang, B., Fu, Z., Wang, J., Tang, X., Zhao, Y., \& Zhang, L. (2017). Effect of householder characteristics, production, sales and safety awareness on farmers' choice of vegetable marketing channels in Beijing, China. British Food Journal, 119(6), 1216-1231. https://doi.org/10.1108/BFJ-08-2016-0378

Journal of Industrial Engineering and Management, 2019 (www.jiem.org)

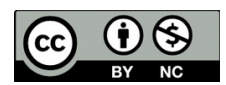

Article's contents are provided on an Attribution-Non Commercial 4.0 Creative commons International License. Readers are allowed to copy, distribute and communicate article's contents, provided the author's and Journal of Industrial Engineering and Management's names are included. It must not be used for commercial purposes. To see the complete license contents, please visit https://creativecommons.org/licenses/by-nc/4.0/. 